\title{
Key statistician ousted as Waxman enters gp160 fray
}

A statistician involved in Army AIDS research work has resigned, alleging that his employer, the Jackson Foundation, is party to a an Army "cover-up" of information surrounding the release of early data on the efficacy of the gp160 therapeutic vaccine.

Bill McCarthy, director of biostatistics at the Maryland-based foundation - a nonprofit, 600 -strong clinical research centre which works primarily for the armed forces - says that it has failed to confront what he regards as shortcomings in data presented by Lt Colonel Bob Redfield, the researcher at the centre of the continuing gp160 controversy, because of its reliance on Army money. McCarthy has been an internal critic of Redfield's work for some time, and his resignation from the Jackson Foundation appears to have been forced after a row there over the alleged leaking of information to the press.

Meanwhile, Congressman Henry Waxman (Democrat, California), chair of the House health and environment subcommittee, has written to health secretary Donna Shalala expressing his concern about the fate of a proposed large-scale gp 160 vaccine trial, and asking for an update on it. Responsibility for the $\$ 20$ million trial, which was transferred earlier this year from the Army to the National Institutes of Health, has now reverted to the Department of Defense (see Nature 363, 294; 1993).

McCarthy's exit appears to mark a victory for the Army research faction that endorses Redfield's belief in the efficacy of gp 160 vaccine as a treatment for HIV-infected patients.

But after McCarthy resigned, he made public a series of allegations about the management of Army AIDS research and the role of his former employer. McCarthy says that: - Data presented by Redfield at the international AIDS conference in Amsterdam last year was at odds with the actual results of the Army's Phase $1 \mathrm{gp} 160$ trial;

- The subsequent Army investigation, whose results have yet to be officially released but which is known to have exonerated Redfield of scientific misconduct, was a "whitewash" which failed to adequately address the legitimacy of the Amsterdam paper;

- Management at the Jackson Foundation, where Redfield and his Army colleagues conduct much of their AIDS research, has turned a blind eye to this because of its reliance on Army funding.

McCarthy says that his own statistical analysis of the results of the Phase $1 \mathrm{gp} 160$ trial shows that "done properly, you could not get the results given by Redfield in Amsterdam or subsequently".

The army investigators, he claims, "gave a sense that the investigation was primarily a damage control exercise." Of John Lowe, the Jackson Foundation's director, he says: "Whenever I tried to get him to do the right thing, he'd get mad at me for jeopardizing [the Foundation's] Army connection."

Lowe has not responded to requests for interview. Lisa Reilly, a spokeswoman for the Jackson Foundation, says: "DrMcCarthy resigned for personal reasons. The foundation has a policy of not discussing matters regarding former employees".

\section{Discounts offered for large-scale users of Taq}

Washington. Roche Molecular Systems (RMS) and Perkin-Elmer Corporation this week agreed to offer discount on Taq DNA polymerase for large-scale users, because of pressure from the scientific community. The companies also hope that cutting the cost of the enzyme, which drives the polymerase chain reaction $(\mathrm{PCR})$, will stimulate new applications for PCR.

Under the bulk discount programme, Roche and Perkin-Elmer will drop the unit price of AmpliTaq Taq polymerase for laboratories that purchase more than 250,000 units of the enzyme a year; above this, the price per unit will be further discounted depending on annual consumption.

Through a system of matching volumefor-volume grants, the companies plan to cut the unit price of the enzyme by half again to all designated National Center for Human Genome Research (NCHGR) Genome, Science and Technology Centers (see figure for the new pricing schedule).

Stanley Rose, director of PCR products in the Applied Biosystems division of Perkin-Elmer does not anticipate any sig-

\section{Pricing scheme for Taq}

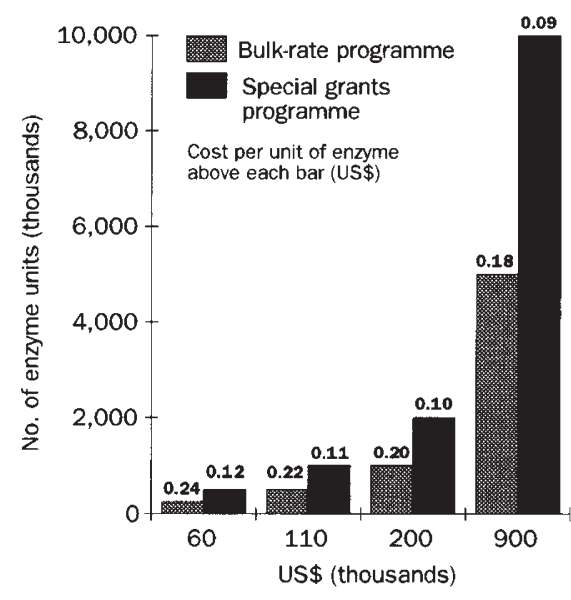

A spokesman for the Walter Reed Army Institute, Marvin Rogul, denies there has been any cover-up, and defends the Army record on AIDS research. "When you have clinical trials there is always some room for differences of opinion," he says. Referring to Redfield's release of efficacy data at Amsterdam, which McCarthy says was premature, Rogul says: "If you don't give out data you get accused of holding it back."

Rogul says that the Army was still negotiating with gp 160 producer MicroGeneSys about the provision of free vaccine for a single product, Phase 3 trial. If negotiations fail, he points out, the $\$ 20$ million allocated for the trial will revert to the Army AIDS research budget. Comment on how that money might be spent would be "presumptuous", Rogul says.

Colin Macilwain nificant delays in implementing similar pricing schemes for large-scale genome mapping and sequencing laboratories in Europe and Japan.

In a related development last week, the companies loosened their stranglehold on the supply of Taq polymerase. They granted Boehringer Mannheim a non-exclusive licence, valid for the term of Roche's PCR patents, which provides the company with worldwide rights to make and sell the enzyme for use in PCR in all fields other than in vitro diagnostics.

Boehringer Mannheim already sells Taq polymerase for non-PCR applications (although it cannot police how researchers use it). Now it can compete with Perkin-Elmer which previously had sole rights to sell PCR products made by RMS in these markets.

Researchers greeted news of the pricing programme enthusiastically. Dr David Schlessinger of the department of molecular microbiology at Washington University School of Medicine called it a "salutary development". Dr. Francis Collins, who in April succeeded James Watson as director of the National Institutes of Health's NCHGR, called it a "win-win" situation. In a recent poll of 13 genome centres, which were paying an average of $\$ 0.30$ per unit of enzyme, Collins estimated the centres were spending as much as 12 per cent of their budget on Taq alone; under the new pricing scheme, the cost per unit for a centre using, for example, more than one million units annually would drop by about a third to $\$ 0.10$.

President of the Human Genome Organisation and director of the institute for molecular genetics at Baylor College of Medicine, Dr C. Thomas Caskey, says he had hoped Roche would open up the market to more than one other supplier. Nevertheless, "it's a step forward," he says, acknowledging that RMS has come a long way over the past year or so: "I think they realize that there were some mistakes made early on", he says.

Diane Gershon 